\title{
STUDI PENGEMBANGAN WEBGIS SARANA DAN PRASARANA PELABUHAN (STUDI KASUS: TANJUNG PERAK SURABAYA)
}

\author{
Rizkia Amaliyah Maryam, Hepi Hapsari Handayani \\ Jurusan Teknik Geomatika FTSP-ITS, Kampus ITS Sukolilo, Surabaya, 60111 \\ Email : hapsari@geodesy.its.ac.id
}

\begin{abstract}
Abstrak
Pelabuhan Tanjung Perak merupakan salah satu pelabuhan pintu gerbang di Indonesia, yang menjadi pusat kolektor dan distributor barang ke Kawasan Timur Indonesia, khususnya untuk Propinsi Jawa Timur. Karena letaknya yang strategis dan didukung oleh daerah hinterland Jawa Timur yang potensial maka Pelabuhan Tanjung Perak juga merupakan pusat pelayaran interinsulair Kawasan Timur Indonesia.

Pada penelitian ini akan dilakukan pembuatan sistem informasi geografis berbasis Web mengenai sarana dan prasarana Pelabuhan Tanjung Perak dengan menggunakan Citra Resolusi Tinggi Worldview-2, Peta Kawasan Pelabuhan Tanjung Perak 2012 dan basis data Sarana dan Prasarana Pelabuhan meliputi Terminal Penumpang Darat, Terminal Penumpang Laut, Gudang, Lapangan Penumpukan, Pasar, Perkantoran, Lapangan Parkir. Sedangkan fokus sarana dan prasarana yang digunakan adalah Gudang, Lapangan Penumpukan, dan Terminal Penumpang yang meliputi area Terminal Jamrud, Mirah, Berlian dan Kalimas.
\end{abstract}

Hasil penelitian ini menunjukkan perbandingan perubahan sarana dan prasarana di Kawasan Pelabuhan Tanjung Perak mengalami perubahan yang signifikan pada area gudang, lapangan penumpukan, dan terminal penumpang tahun 2012-2013. Dimana terdapat penambahan luasan gudang sebesar 67,610 \%, Kemudian terdapat penambahan pada lapangan penumpukan sebesar $80,075 \%$. Dan pada terminal penumpang terdapat penambahan sebesar $24,637 \%$ dan pengurangan sebesar $35,795 \%$.

Kata Kunci : Pelabuhan, Sarana Dan Prasarana, SIG, Web, Perkembangan Kawasan

\section{PENDAHULUAN}

\section{Latar Belakang}

Menurut Peraturan Pemerintah Republik Indonesia Nomor 61 Tahun 2009 Pasal 1 Ayat 1, pelabuhan adalah tempat yang terdiri atas daratan dan/atau perairan dengan batas- batas tertentu sebagai tempat kegiatan pemerintahan dan kegiatan pengusahaan yang dipergunakan sebagai tempat kapal bersandar, naik turun penumpang, dan/atau bongkar muat barang, berupa terminal dan tempat berlabuh kapal yang dilengkapi dengan fasilitas keselamatan dan keamanan pelayaran dan kegiatan penunjang pelabuhan serta sebagai tempat perpindahan intra-dan antarmoda transportasi.

Pelabuhan Tanjung Perak merupakan salah satu pelabuhan pintu gerbang di Indonesia, yang menjadi pusat kolektor dan distributor barang ke Kawasan Timur Indonesia, khususnya untuk Propinsi Jawa Timur. Karena letaknya yang strategis dan didukung oleh daerah hinterland Jawa Timur yang potensial maka Pelabuhan Tanjung Perak juga merupakan pusat pelayaran interinsulair Kawasan Timur Indonesia. Dahulu, kapal-kapal samudera membongkar dan memuat barang-barangnya melalui tongkang-tongkang dan perahu-perahu yang dapat mencapai Jembatan Merah (pelabuhan pertama pada waktu itu) yang berada di jantung kota Surabaya melalui Sungai Kalimas.

Salah satu alternatif yang dapat digunakan untuk melakukan pemantauan perubahan sarana dan prasarana kawasan Pelabuhan dapat dilakukan dengan menggunakan teknologi penginderaan jauh dan Sistem Informasi Geografis (SIG). Perencanaan pengelolaan dan pengambilan keputusan yang tepat harus dilandasi oleh data dan informasi yang yang akurat tentang kondisi lahan dengan demikian harus dilakukan pemantauan kesesuaian lahan, penggunaan 
teknologi GIS dapat mempermudah analisis kesesuaian lahan pada suatu kawasan/wilayah yang luas[3]. Sistem Informasi Geografis (SIG) dan data Penginderaan Jauh dapat diaplikasikan untuk mengevaluasi perubahan sarana dan prasarana kawasan Pelabuhan Tanjung Perak Surabaya. Dimana dengan diperbaharuinya Gudang, Lapangan Penumpukan dan Terminal penumpang kemudian dapat dievaluasi keterkaitannya dengan peningkatan maupun pengurangan produktivitas pelabuhan.

\section{Perumusan Masalah}

Dari latar belakang diatas, dapat diperoleh perumusan masalahnya, yaitu: "Bagaimana mengevaluasi produktivitas sarana dan prasarana di kawasan Pelabuhan Tanjung Perak Surabaya menggunakan SIG berbasis Web

\section{METODOLOGI PENELITIAN}

\section{Lokasi Penelitian}

Lokasi penelitian ini mengambil wilayah kawasan Pelabuhan Tanjung Perak meliputi area Terminal Jamrud, Kalimas, Mirah dan Berlian yang terletak di Kelurahan Perak Timur, Kecamatan Pabean Cantikan, Kota Surabaya, Propinsi Jawa Timur yang memiliki posisi geografis $7^{\circ} 11^{\prime} 50^{\prime \prime}$ - 70 $13^{\prime} 20^{\prime \prime}$ LS dan $112^{\circ} 44^{\prime} 100^{\prime \prime}$ - $112^{\circ} 32^{\prime} 40^{\prime \prime}$ BT

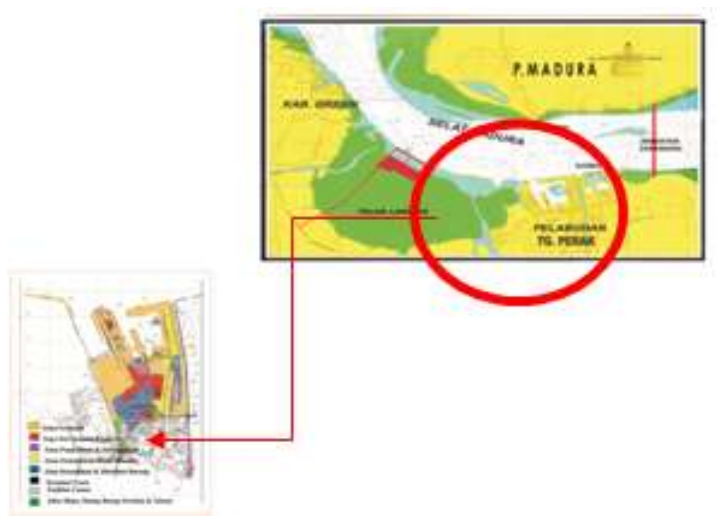

Gambar 1. Lokasi Penelitian

\section{Data Dan Peralatan}

- Data

Data yang digunakan dalam penelitian tugas akhir ini adalah sebagai berikut :

1. Citra satelit yang digunakan adalah citra satelit Worldview 2013 dengan resolusi mencapai 2 meter dan dipadu dengan pengamatan lapangan
2. Peta Garis Kota Surabaya dengan skala 1:1000 Dinas Cipta Karya 2012

3. Peta kawasan Pelabuhan Tanjung Perak skala 1: 1000 PT. Pelindo III 2012

4. Data Operasional Pelabuhan Tanjung Perak Tahun 2012-2013 PT. Pelindo III

\section{- Peralatan}

Peralatan yang digunakan dalam penelitian ini meliputi :

GPS Navigasi Software Pengolahan Citra, Arcgis 10.2, MySQL, XAMPP, Browser, Phpmyadmin, Notepad++, Google Map Engines, Google Drive

\section{Tahapan Penelitian}

Tahapan yang dilaksanakan dalam pengolahan data ini sebagai berikut :

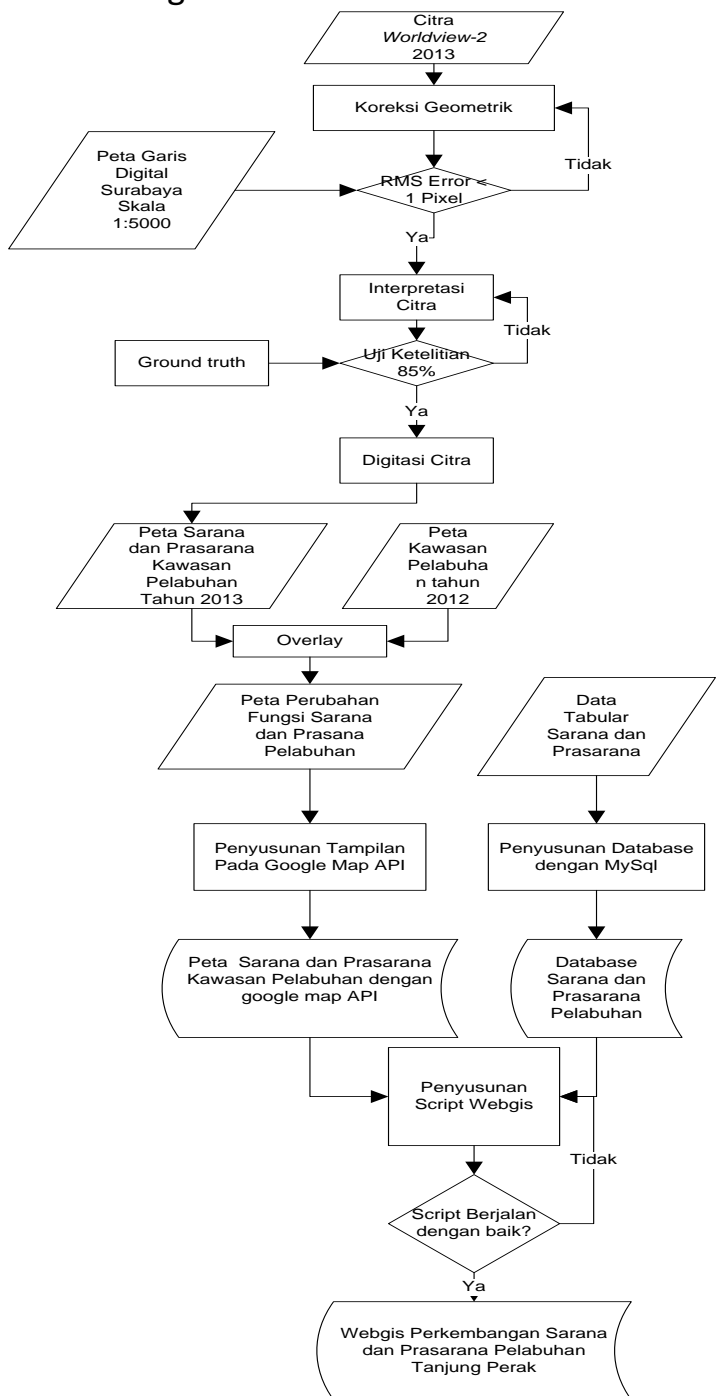

Gambar 2. Diagram Alir Tahapan Pengolahan Data Spasial 
Berikut adalah penjelasan diagram alir tahapan pengolahan data spasial:

1. Koreksi geometrik

Koreksi geometrik dilakukan dengan merektifikasi citra Worldview 2013 yang ada, sehingga geometri citra bersifat planimetrik. Rektifikasi citra memerlukan titik kontrol medan (Ground Control Point) yang dapat dicari pada peta/citra orthorektifikasi dengan koordinat yang sama atau dengan melakukan pengukuran koordinat langsung di lapangan dengan GPS (Global Positioning System).

\section{Interpretasi citra}

Interpretasi citra dilakukan dengan memeriksa gambar citra untuk tujuan mengidentifikasi objek dan menilai signifikansi mereka. Yang paling dasar dari prinsip-prinsip ini adalah unsur-unsur interpretasi citra diantaranya: lokasi, ukuran, bentuk, bayangan, nada / warna, tekstur, pola, tinggi/kedalaman dan situs/situasi/asosiasi. Unsur-unsur ini digunakan untuk menginterpretasi setiap sarana dan prasarana pada citra yang ada.

3. Uji ketelitian

Melakukan pengecekan lapangan (sampel area) yang dipilih dari setiap bentuk penutup/penggunaan lahan. Uji ketelitian dilakukan pada setiap area sarana dan prasarana, dan diuji kebenarannya di lapangan (Ground Truth).

\section{Digitasi Citra}

Dari citra yang telah diuji ketelitiannya, dilakukan proses digitasi untuk mendapatkan peta sarana dan prasarana pelabuhan.

\section{Overlay}

Menumpangtindihkan dua peta yang ada kemudian dianalisa perubahannya dari tahun ke tahun.

6. Integrasi data
Merupakan proses penggabungan peta dengan atribut dalam basis datanya yang kemudian menjadi Sistem Informasi Geografis.

\section{Pembuatan Webgis}

Pada tahapan ini, disusun script yang kemudian akan dijadikan bahan untuk menyusun webGIS.

\section{HASIL DAN PEMBAHASAN \\ Koreksi Geometrik}

Pada proses ini dilakukan koreksi geometrik terhadap citra yang sudah ada menggunakan software pengolah citra. Dimana citra tersebut dikoreksi menggunakan peta yang sudah ada sebelumny yakni, Peta Garis Digital Kota Surabaya skala 1:1000.

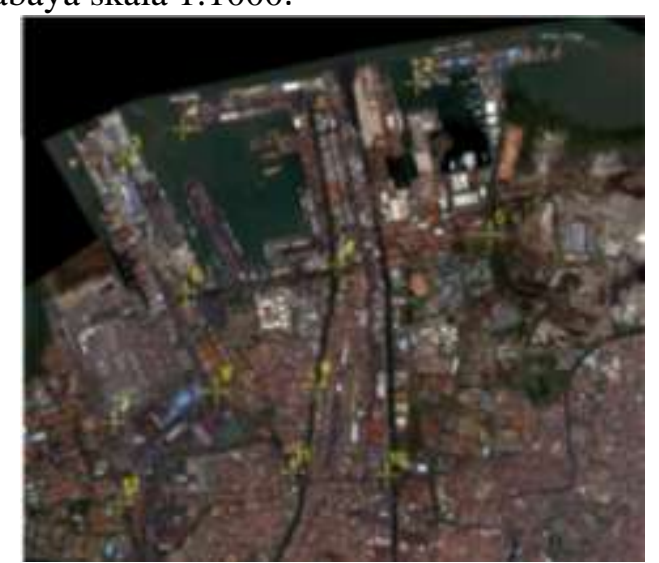

\section{Gambar 3. Posisi Ground Control Point (GCP) pada} citra Worldview-2 tahun 2013

Berikut merupakan hasil penghitungan Root Mean Square (RMS). Penghitungan dilakukan pada saat melakukan posedur koreksi geometrik. Batas kesalahan pada proses koreksi geometrik adalah 0.5 atau 1 pixel satu sama lain atau sekitar 10 meter. Bila nilai pergeseran titik lebih dari batas toleransi yang diberikan, maka koreksi wajib diulang.

Tabel 1 Hasil perhitungan nilai RMS pada citra Worldview-2 tahun 2013

\begin{tabular}{cc}
\hline Titik & RMS \\
\hline $\mathbf{1}$ & 0.74 \\
$\mathbf{2}$ & 0.14 \\
$\mathbf{3}$ & 0.18 \\
$\mathbf{4}$ & 0.31 \\
$\mathbf{5}$ & 0.15 \\
\hline
\end{tabular}




\begin{tabular}{cc}
\hline $\mathbf{6}$ & 0.11 \\
$\mathbf{7}$ & 0.83 \\
8 & 0.41 \\
9 & 0.73 \\
10 & 0.17 \\
11 & 0.04 \\
12 & 0.46 \\
RMS Total & $\mathbf{0 , 3 5}$ \\
\hline
\end{tabular}

\section{Interpretasi Citra}

Citra yang sudah dikoreksi kemudian diinterpretasi . tidak lupa kemudian dilakukan uji ketelitian interpretasi citra $\mathrm{Uji}$ ketelitian interpretasi citra dilakukan untuk mengetahui kebenaran hasil interpretasi citra dengan cara membandingkan antara data hasil interpretasi dengan data yang sebenarnya di lapangan.

Tabel 2 Koordinat sarana dan prasarana hasil pengukuran GPS Navigasi di lapangan

\begin{tabular}{|c|c|c|c|}
\hline \multirow{2}{*}{ No } & \multirow{2}{*}{ Nama } & \multicolumn{2}{|c|}{ Koordinat Hasil Ground Truth } \\
\hline & & $X(m)$ & $Y(m)$ \\
\hline 1 & $\begin{array}{c}\text { Terminal } \\
\text { Penumpang } \\
\text { Laut }\end{array}$ & 225531,096 & 704195,125 \\
\hline 2 & $\begin{array}{c}\text { Terminal } \\
\text { Penumpang } \\
\text { Darat }\end{array}$ & 225898,860 & 703935,486 \\
\hline 3 & Tempat Ibadah & 225826,047 & 704003,900 \\
\hline 4 & Pras Perbankan & 225897,061 & 702993,833 \\
\hline 5 & Pras Olahraga & 226013,449 & 703246,411 \\
\hline 6 & Pras Kesehatan & 226073,168 & 702900,013 \\
\hline 7 & Pertokoan & 225816,492 & 703549,811 \\
\hline 8 & Pasar & 225834,229 & 704139,178 \\
\hline 9 & Lapangan Parkir & 225508,941 & 704115,643 \\
\hline 10 & $\begin{array}{l}\text { Lapangan } \\
\text { Penumpukan }\end{array}$ & 225819,683 & 703087,027 \\
\hline 11 & Kantor & 226023,927 & 702964,836 \\
\hline 12 & Gudang & 225977,095 & 703693,192 \\
\hline 13 & Gate & 225613,263 & 702979,167 \\
\hline
\end{tabular}

Dari hasil ground truth lapangan menggunakan GPS Handheld Navigasi. Didapat perbedaan posisi yang cukup besar antara posisi hasil ground truth dengan posisi hasil dijitasi citra. Hal ini dapat disebabkan karena ketelitian alat GPS Handheld Navigasi yang kurang baik yaitu antara $10-15$ meter dan juga dapat disebabkan oleh faktor multipath karena lokasi yang disurvey adalah lokasi yang banyak ditumbuhi pepohonan rindang sehingga menyebabkan posisi hasil pengukuran GPS tidak sesuai dengan posisi sebenaranya.

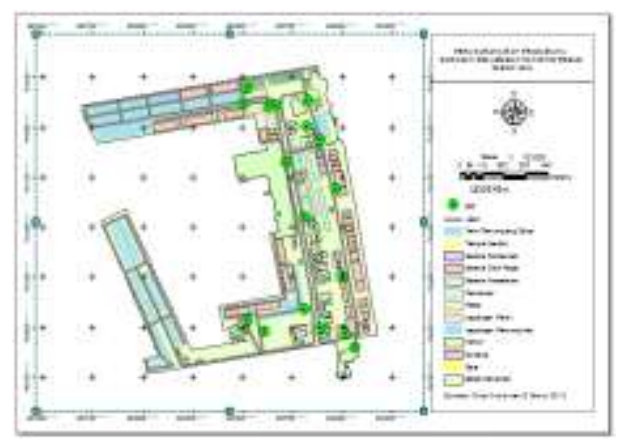

Gambar 3 Lokasi Titik Hasil Pengukuran GPS Navigasi

Walaupun hasil pengukuran GPS Navigasi tidak sesuai dengan posisi sebenarnya, hal ini tidak mempengaruhi ketelitian planimetris dari peta hasil dijitasi yang dilakukan dalam penelitian ini. Analisa ketelitian planimetris akan dibahas pada sub-bab selanjutnya. Pengukuran dengan GPS Navigasi dilakukan hanya untuk tujuan analisa ketelitian interpretasi.

Sampel lapangan yang digunakan adalah sebanyak 104 lokasi yang terdiri dari 3 lokasi terminal penumpang laut, 1 lokasi terminal penumpang darat, 22 lokasi gudang, 19 lokasi lapangan penumpukan, 42 lokasi perkantoran, 3 lokasi sarana ibadah, 2 lokasi sarana perbankan, 1 lokasi sarana olahraga, 1 sarana kesehatan, 7 area pertokoan, 1 area pasar, 2 lapangan parkir, dan 7 gate.

Setelah dilakukan pencocokkan terhadap kondisi di lapangan, didapatkan error di 2 lokasi lahan kosong yang ada di citra ternyata sudah berubah peruntukkan lahannya pada kondisi sebenarnya. Error yang didapat kebanyakan disebabkan karena citra yang digunakan adalah citra tahun 2013 sementara waktu pencocokkannya dilakukan pada tahun 2013, sehingga besar kemungkinan terjadi perubahan peruntukkan lahan.

Uji ketepatan interpretasi citra Pelabuhan Tanjung Perak menggunakan rumus :

$K I=$

$$
\frac{J K I}{J S L} x 100 \% \ldots \ldots \ldots \ldots \ldots \ldots \ldots \ldots \ldots \ldots \ldots \ldots \ldots \ldots \ldots \ldots
$$


Dimana:

JSL = Jumblah objek yang diinterpretasi

Error = jumblah oebjek error pada interpretasi

$J K I=J S L-$ Error

Sehingga :

JSL $=104$

Error $=2$

$J K I=104-2=102$

$K I=\frac{102}{104} x 100 \%$

$K I=98.07 \%$

Dengan nilai $K I=98.07 \%$ pada citra Pelabuhan Tanjung Perak, berarti interpretasi dianggap benar karena sudah memen uhi toleransi yang ada yaitu di atas $80 \%$.

\section{Digitasi Citra}

Citra yang sudah terkoreksi secara geometrik dan sudah diuji ketelitian interpretasinya kemudian diekspor ke dalam software ArcGIS 10.2 untuk dilakukan digitasi area yang merupakan sarana dan prasarana pelabuhan sehingga dihasilkan peta sarana dan prasarana kawasan Pelabuhan Tanjung Perak. Kemudian hasil dijitasi dikonversi ke dalam format *. kml.

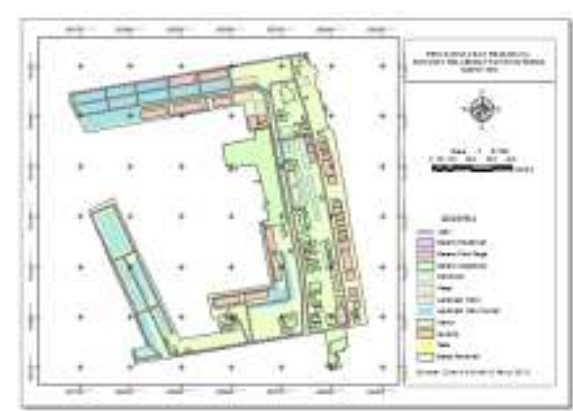

Gambar 4 Hasil dijitasi citra Worldview-2 wilayah Pelabuhan Tanjung Perak

Dalam kajian ini digunakan peta kawasan Pelabuhan Tanjung Perak tahun 2012 yang dikeluarkan oleh PT. Pelindo 3. Dimana peta tersebut tersimpan dalam bentuk *.dwg yang kemudian diubah ke dalam bentuk *.shp sehingga bisa dianalisa lebih lanjut.

Setelah kedua peta tersimpan dalam bentuk *.shp kemudian dilakukan proses overlay dengan peta kawasan Pelabuhan Tanjung Perak pada tahun
2012 dengan menggunakan beberapa menu pada ArcGIS sebagai berikut:

a) Menu Feature to polygon untuk mengubah peta kawasan Pelabuhan Tanjung Perak 2012 yang berupa polyline menjadi polygon.

b) Menu erase untuk memotong area yang bertampalan sehingga bisa dilihat perubahan apa saja yang terjadi dari peta hasil dijitasi dengan peta kawasan pelabuhan tahun 2012 yang sudah ada.

c) Menu calculate geometry untuk mengetahui masing-masing luasan dari hasil perubahan yang ada.

d) Join Table dimaksudkan untuk menggabungkan atribut yang sudah dibuat.

\section{Overlay Peta}

Dari peta kawasan pelabuhan 2012 dan peta fungsi sarana dan prasarana 2013 yang ada didapatkan perubahan sarana dan prasarana kawasan pelabuhan dari tahun 2012 ke 2013 dengan adanya penambahan luasan area gudang, lapangan penumpukan, dan terminal penumpang maupun pengurangan luasan pada fungsi terminal penumpang, lapangan penumpukan dan gudang.

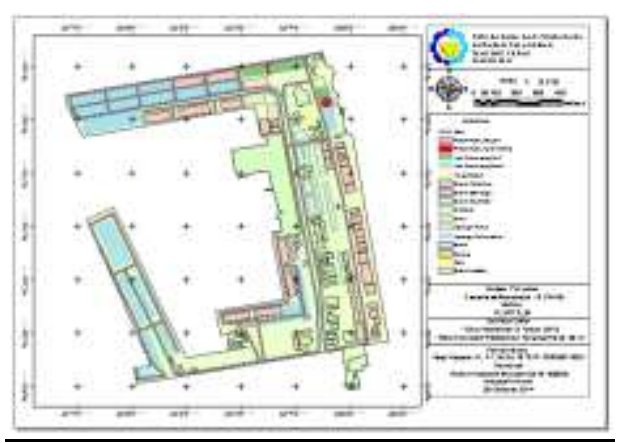

Gambar 5 Tampilan Peta Penambahan Luasan Sarana dan Prasarana Pelabuhan

Dari kajian ini didapatkan hasil bahwa terdapat perubahan luasan sarana dan prasarana pelabuhan Tanjung Perak dari tahun 2012-2013 dalam tabel berikut ini:

Tabel 3 Perubahan Luasan

\begin{tabular}{llll}
\hline No & Nama fungsi & $\begin{array}{l}\text { Pengurangan } \\
\left(\mathbf{m}^{\mathbf{2}}\right)\end{array}$ & $\begin{array}{l}\text { Penambahan } \\
\left(\mathbf{m}^{\mathbf{2}}\right)\end{array}$ \\
\hline 1 & Gudang & $48.825,088$ & $51.174,479$ \\
2 & $\begin{array}{l}\text { Lapangan } \\
\text { Penumpukan }\end{array}$ & $17.498,113$ & $106.976,175$ \\
3 & $\begin{array}{l}\text { Terminal } \\
\text { Penumpukan }\end{array}$ & $5.707,866$ & $3.928,592$ \\
\hline
\end{tabular}


Dari tabel di atas diketahui bahwa terdapat penambahan luasan gudang sebesar 67,610\%, dan pengurangan luasannya sebesar 7,864 \%. Kemudian terdapat penambahan pada lapangan penumpukan sebesar $80,075 \%$ dan Pengurangannya sebesar $13,098 \%$ dan pada terminal penumpang terdapat penambahan sebesar 24,637 \% dan pengurangan sebesar $35,795 \%$. Penambahan drastis ini disebabkan adanya alih fungsi terminal yang mengubah gudangnya menjadi lapangan penumpukan. Sehingga dapat diambil kesimpulan bahwa penambahan luasan dan perluasan berdasarkan fungsi sarana dan prasarananya berbanding dengan total perubahan luasannya dapat dijelaskan dalam gambar 6 dan 7

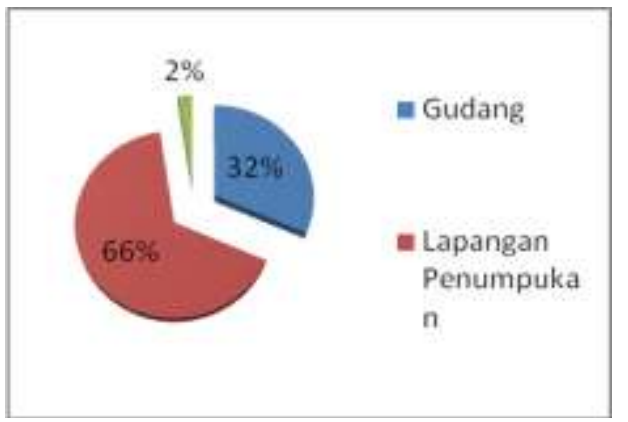

Gambar 6 Tampilan Pernambahan Luasan Sarana dan Prasarana Kawasan Pelabuhan Tanjung Perak

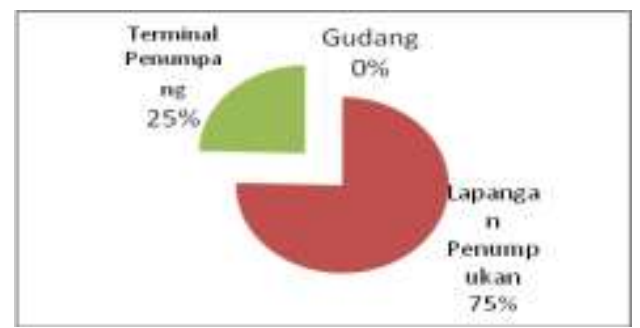

Gambar 7 Tampilan Pengurangan Luasan Sarana dan Prasarana Kawasan Pelabuhan Tanjung Perak

Perubahan ini disebabkan oleh faktor-faktor berikut ini:

a) Perubahan peruntukan area terminal

b) Contohnya pada terminal berlian, dimana sebelumnya terdapat 5 buah gudang yang kemudian dialihfungsikan sebagai lapangan penumpukan. Hal ini disebabkan peralihan peruntukan terminal Berlian yang sebelumnya menerima pengiriman jenis barang curah, kemudian sekarang hanya menerima barang dalam bentuk peti kemas saja.

c) Renovasi sarana dan prasarana. d) Seperti halnya pada Terminal Penumpang Gapura Surya yang merupakan terminal modern yang akan diresmikan PT. Pelindo III akhir Desember 2013 ini. Terminal ini merupakan terminal penumpang yang direnovasi menjadi terminal penumpang modern.

\section{Penyusunan tampilan pada google map API}

Dengan menggunakan software ini, sehingga dapat diimport dan diembed pada aplikasi web GIS yang akan dibuat dengan langkah langkah sebagai berikut:

a. Importing file *. $\mathrm{kml}$

Dalam tahapan ini filet yang sebelumnya sudah dibuat dalam bentuk *.shp diubah atau disimpan kembali dalam format *.kml dan agar dapat ditampilkan pada Google Map Engine. Setelah dimasukkan untuk tampilan dan warna bisa diubah berdasarkan beberapa pilihan. Baik itu berdasarkan fungsi, label maupun jenis bangunan.

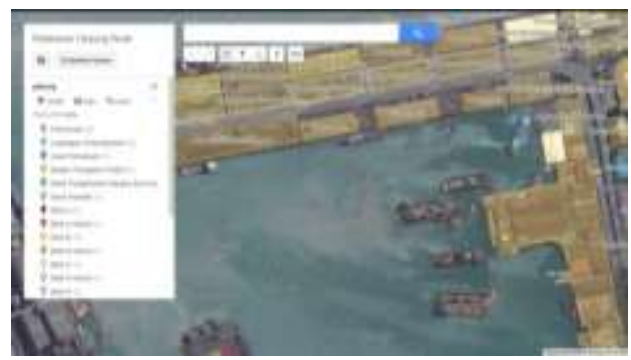

Gambar 8 Hasil Import File pada Google Maps Engine

b. Penyusunan database pada Mysql

Dilanjutkan dengan pembuatan database, database yang digunakan menggunakan nama "drasticdata" dengan memiliki 24 tabel. Database dan tabel yang akan digunakan dalam pembuatan aplikasi ini sesuai dengan fungsi yang diinginkan.

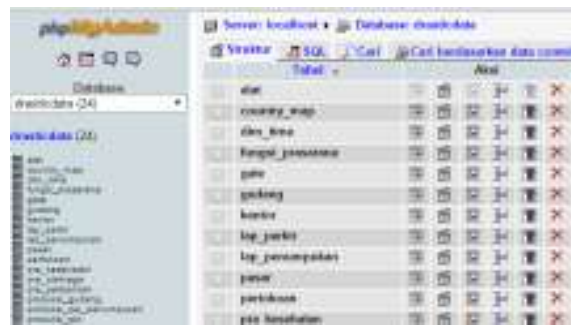

Gambar 9 Tampilan database pada phpmyadmin 


\section{c. Penyusunan script webgis}

Untuk dapat menampilkan database, google map engine dalam sebuah web maka dibuat script koneksi database dengan aplikasi yang berada pada folder htdocs di program Xampp. Sebelum membuat program maka terlebih dahulu dibuat folder dengan nama "Webgis" pada program Xampp.

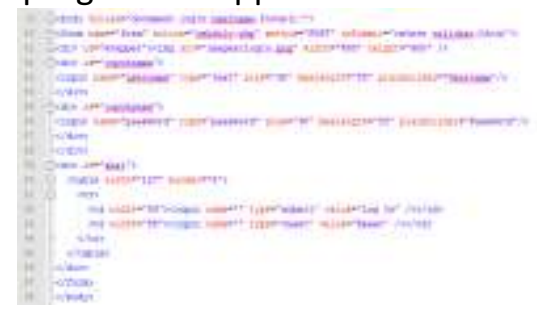

\section{Gambar 10 Tampilan Contoh Script untuk login. Tampilan aplikasi}

Pembuatan program aplikasi ini menggunakan bahasa PHP HTML dengan Jquery sebagai penyusun koding. Untuk menampilkan aplikasi ini digunakan software brower seperti Chrome, Mozilla dan semacamnya.

Pembuatan program aplikasi ini, dibuat beberapa interface, yaitu:

a. Tampilan Login untuk masuk kedalam aplikasi.

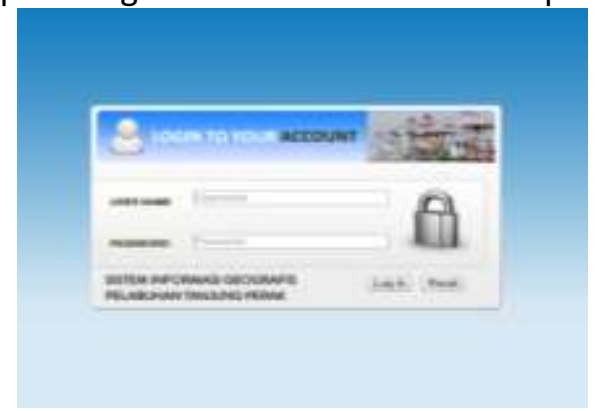

Gambar 11 Tampilan Log in

b. Halaman Utama mengenai judul aplikasi dan menu utama aplikasi sebagai pengarah dan petunjuk ke menu-menu lainnya.

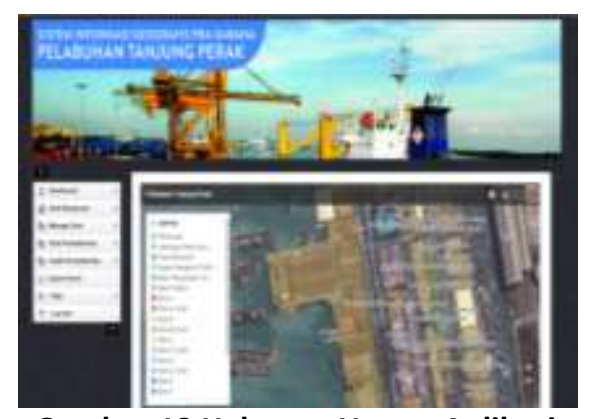

Gambar 12 Halaman Utama Aplikasi c. Halaman Editing Dashboard mengenai mengedit peta baik itu berupa perubahan bentuk, foto atau gambar, warna tampilan peta yang diinginkan, label, maupun luasan. Menu ini merupakan link langsung pada aplikasi Google Maps Engine yang yang bisa diakses oleh user yang diizinkan.

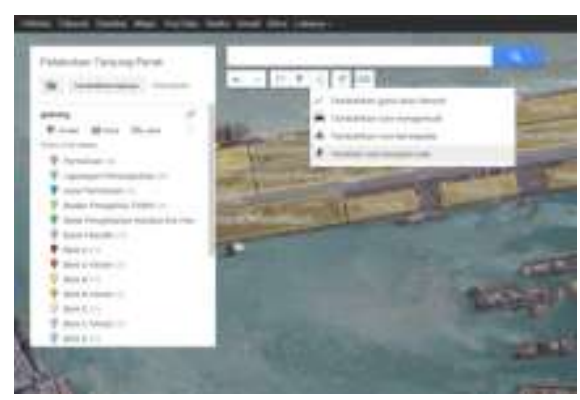

Gambar 13 Editing Dashboard

d. Menu View Bangunan Per Fungsi.

Dimana pada halaman ini User dapat menambahkan secara manual bangunan berdasarkan fungsi. Dengan data atribut yang ada di dalamnya. Hanya saja dalam menu ini data yang bisa ditambahkan Data non spasial

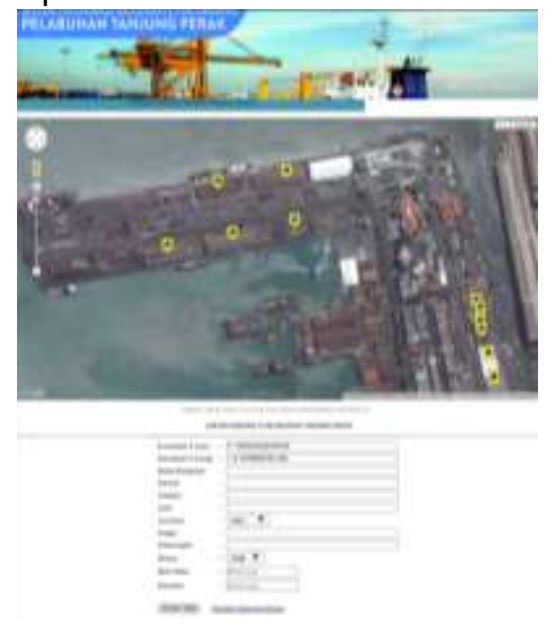

Gambar 14 Menu tambah manual data

e. Menu Manage User untuk mengatur user yang bisa mengakses data dan masuk melihatnya 

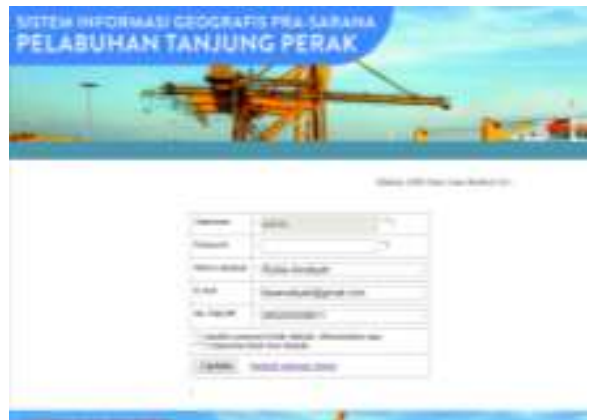

Gambar 15 Manage user aplikasi

f. Menu Manage Data untuk mengatur data baik itu menambahkan atau menghapus. Dalam beberapa fungsi terdapat menu khusus seperti untuk mencaria status dari gudang atau lapangan penumpukan yang berstatus close maupun open. Dan pencarian menggunakan tanggal awal penyewaan maupun tanggal batas akhir penyewaan prasarana.

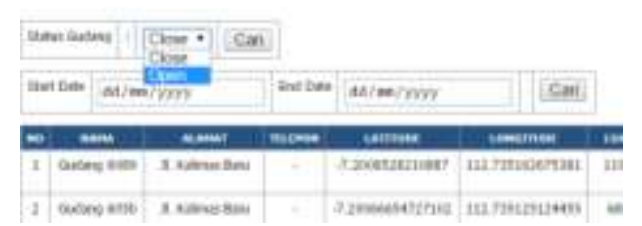

Gambar 16 Pencarian Menggunakan Status Gudang

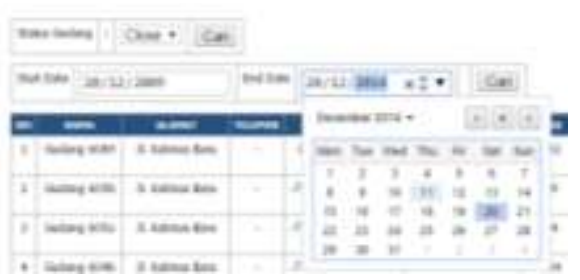

Gambar 17 Pencarian dengan keyword tanggal

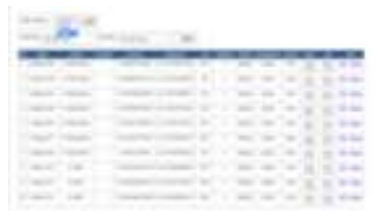

Gambar 18 Tampilan Manage Data

g. Menu Data Produktivitas untuk menampilkan data produktivitas dalam bentuk tabel. Dimana data tersebut dapat ditambah, diubah maupun dihapus.

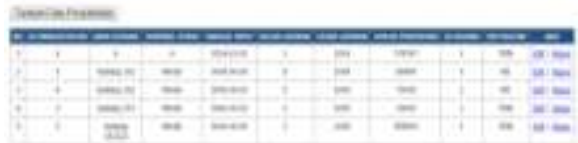

Gambar 19 Tampilan data produktivitas

h. Menu Grafik Produktivitas untuk menampilkan grafik produktivitas dengan memasukkan filter berupa area terminal fungsi, dan tahun. Grafik ini merupakan grafik dinamis yang akan berubah berdasarkan perubagan database yang ada pada aplikasi.

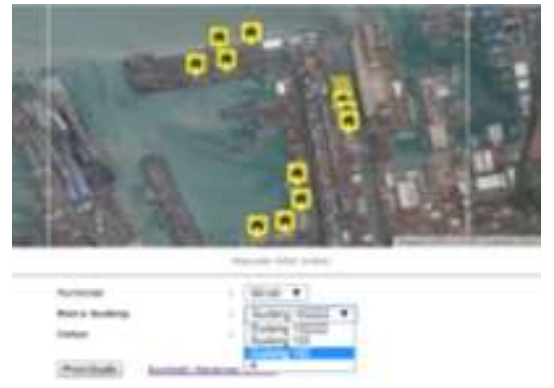

Gambar 20 Tampilan Filtering sebelum menampilkan grafik

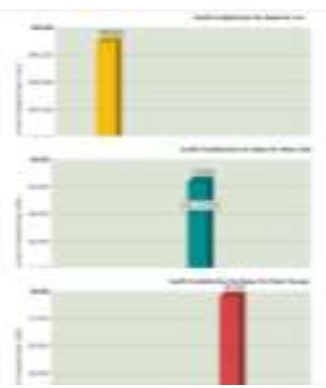

Gambar 21 Tampilan grafik produktivitas

i. Menu Export data ke dalam excel. Dimana data yang sudah ada dapat diexport dalam bentuk excel sesuai dengan keperluan yang dibutuhkan. 


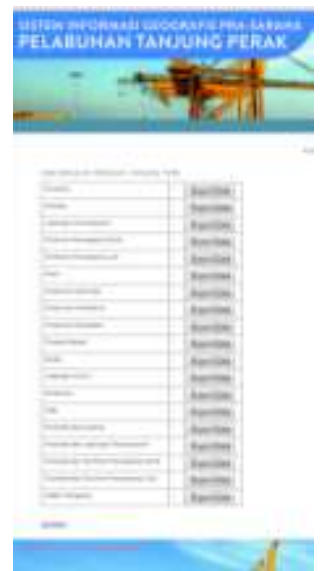

Gambar 22 Tampilan menu ekspor data

\section{PENUTUP}

\section{Kesimpulan}

Berdasarkan hasil penelitian yang telah dilakukan, maka didapatkan beberapa kesimpulan akhir yaitu

1. Berdasarkan Terdapat 3 terminal penumpang laut, 1 terminal darat, 4 sarana ibadah, 2 sarana perbankan, 1 sarana olahraga, 1 sarana kesehatan, 7 area rukan, 1 pasar, 4 lapangan parkir, 24 lapangan penumpukan, 40 kantor, 48 gudang, dan 7 gate di kawasan Pelabuhan Tanjung Perak yang yang tersebar di Area terminal Jamrud, Mirah, Kalimas dan berlian

2. Hasil penelitian ini menunjukkan perbandingan perubahan fungsi sarana dan prasarana di Kawasan Pelabuhan Tanjung Perak mengalami perubahan yang signifikan pada area gudang, lapangan penumpukan, dan terminal penumpang tahun 2012-2013. Dimana terdapat penambahan luasan gudang sebesar $67,610 \%$, dan pengurangan luasannya sebesar 7, $864 \%$. Kemudian terdapat penambahan pada lapangan penumpukan sebesar 80,075\%.dan Pengurangannya sebesar 13,098\%. Dan pada terminal penumpang terdapat penambahan sebesar $24,637 \%$ dan pengurangan sebesar $35,795 \%$

\section{DAFTAR PUSTAKA}

Departemen Perhubungan. 2002. Keputusan Menteri Menteri Perhubungan No. 53 Tahun 2002 Tentang Tatanan Kepelabuhanan Nasional..
Departemen Dalam Negeri. 2009. Peraturan Pemerintah Republik Indonesia Nomor 61 Tahun 2009.

M. Gatheru, P. M. 2010. Evaluation Of Land Suitability For Maize Production Using Geographic Information Systems In Eastern Kenya.

Prayogi, R. 2008. "Studi Tingkat Sedimentasi dan Pola Arus di Pelabuhan Tanjung Perak Surabaya Akibat Perkembangan Bumper BBM". Surabaya; Teknik Kelautan ITS. 